\title{
Biology, population dynamics and secondary production of the green crab Carcinus maenas (L.) in a temperate estuary
}

\author{
A. Baeta $^{\text {a,* }}{ }^{\text {, H.N. Cabral }}{ }^{\text {b }}$, J.M. Neto ${ }^{\text {a }}$, J.C. Marques ${ }^{\text {a }}$, M.A. Pardal ${ }^{\text {a }}$ \\ ${ }^{a}$ IMAR - Institute of Marine Research, Department of Zoology, University of Coimbra, 3004-517 Coimbra, Portugal \\ ${ }^{\mathrm{b}}$ Instituto de Oceanografia, Faculdade de Ciências da Universidade de Lisboa, Campo Grande, 1749-016 Lisboa, Portugal
}

Received 29 November 2004; accepted 2 May 2005

Available online 23 June 2005

\begin{abstract}
The biological features, population dynamics and secondary production of Carcinus maenas were studied between June 2003 and June 2004 in four areas within the Mondego estuary, Portugal. Benthic samples were collected monthly, during the night, at high water of spring tides using a 2-m beam trawl, and plankton samples were collected monthly, during the day, at high tide with a Bongo net. Only the first zoeae stage of $C$. maenas larvae was found in the plankton; it was collected at all sampling stations throughout the year. A continuous pattern of benthic recruitment was observed in the upstream areas of the estuary with the highest peaks occurring in the spring 2004. Females carrying eggs were also caught through the year, although mainly in downstream areas. Juveniles' sex-ratio was favourable to males at almost all the sites sampled. Ventral carapace colour varied between green and orange-red, with the proportion of the green morphotype increasing with the increasing distance from the mouth of the estuary. The proportion of crabs in moult also increased from downstream to upstream areas. For both sexes the crab population showed a similar size structure throughout the year. The upstream areas of the estuary were characterized by the dominance of juveniles, with adults migrating to downstream areas. The average annual production of $C$. maenas, $P$ (growth production), was estimated at $0.08 \mathrm{~g} \mathrm{~m}^{-2} \mathrm{y}^{-1}$ AFDW, and the average annual biomass $(\bar{B})$ was estimated at $0.058 \mathrm{~g} \mathrm{~m}^{-2}$, resulting in a $P / \bar{B}$ ratio of 1.4 .
\end{abstract}

(C) 2005 Elsevier Ltd. All rights reserved.

Keywords: Carcinus maenas; recruitment; carapace colour; population dynamics; secondary production; temperate estuary

\section{Introduction}

Carcinus maenas (L.) (Decapoda, Portunidae) is a widely distributed epibenthic species that inhabits hard and soft intertidal shallow habitats of European coasts and estuaries. This species is also found in the north-western Atlantic, and has recently colonized some areas in southern Africa, Australia and Pacific coast of North America (Cohen et al., 1995). It has a complex life cycle with four pelagic zoeae and a megalopae (postlarval) stage that settles and metamorphoses into

\footnotetext{
* Corresponding author.

E-mail address: asbaeta@ci.uc.pt (A. Baeta).
}

the first benthic crab stage. The duration of development from the first zoeae to the megalopae stage varies from 18 to 42 days, and the duration of the megalopae stage varies from 9 to 16 days, depending on temperature (Dawirs and Dietrich, 1985; Mohamedeen and Hartnoll, 1989).

Juvenile crabs tend to remain in the high intertidal zone, whereas adults tend to perform vertical migrations, withdrawing to the subtidal zone during low tide (Crothers, 1968; Hunter and Naylor, 1993; Warman et al., 1993). Different physiological and behavioural responses are known to take place in Carcinus maenas in relation to sex, size and carapace coloration. Intraspecific variability reflects the phenotypic adaptive responses of 
each individual in relation to their ability to withstand environmental variability (McGaw and Naylor, 1992b; Warman et al., 1993; Abelló et al., 1997).

Despite being one of the most studied intertidal crabs, much of our knowledge on Carcinus maenas is based on laboratory studies. Hence, due to its importance in temperate European estuaries and the need to document field data for the species, a monitoring programme was carried out in order to: (1) describe the species life cycle; (2) study the spatial distribution and variability of the species along the estuarine gradient and (3) estimate $C$. maenas secondary production.

\section{Materials and methods}

\subsection{Study site}

The Mondego estuary, a typical temperate intertidal estuary on the western coast of Portugal (Fig. 1), consists of two arms, North and South, with very different hydrological characteristics. The North arm is deeper $(5-10 \mathrm{~m}$ during high tide, tidal range about 2-3 m), while the South arm (2-4 m deep, during high tide) is almost silted up in the upstream areas, which causes the freshwater of the river to flow essentially by the North arm. The water circulation in the South arm is dependent on tides and on the relatively small freshwater input from a tributary, the Pranto River, which is controlled by a sluice. The freshwater discharge from this tributary is regulated according to irrigation needs of the rice crop of Pranto Valley (Pardal et al., 2000, 2004; Martins et al., 2001; Marques et al., 2003; Cardoso

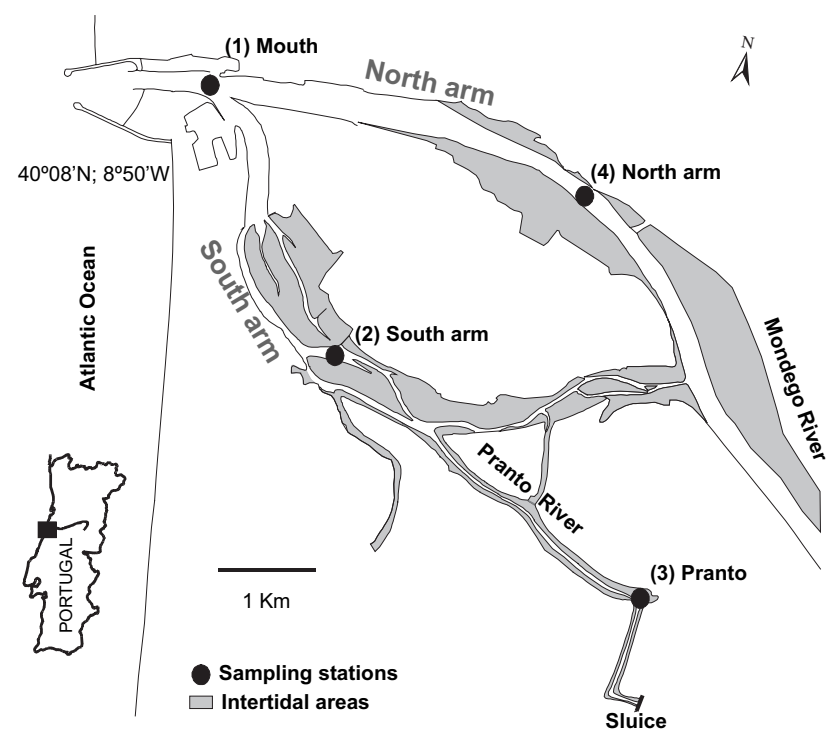

Fig. 1. The Mondego estuary: location of the 4 sampling stations (Mouth, South arm, Pranto and North arm). et al., 2004). Despite some eutrophication, evidenced by occasional spring macro-algal blooms, the South arm appears to be less disturbed by human activities and has apparently more favourable conditions for the development of abundant populations of typical estuarine species (Dolbeth et al., 2003; Cardoso et al., 2004).

The South arm of the Mondego is under anthropogenic stress, which generates an ongoing eutrophication process. The symptoms of such process include seasonal intertidal macroalgal blooms of Enteromorpha spp., among others (Marques et al., 1997, 2003; Pardal et al., 2000, 2004; Martins et al., 2001; Cardoso et al., 2002, 2004; Dolbeth et al., 2003; Verdelhos et al., 2005). A management programme is presently underway, aiming to increase the ecological quality of the system and promote the recovery of seagrass beds, which are presently restricted to the downstream areas of the estuary (Verdelhos et al., 2005).

\subsection{Sampling programme}

The population of Carcinus maenas was sampled monthly, from June 2003 to June 2004, at four stations (Mouth, South arm, Pranto and North arm) (Fig. 1), using a 2-m beam trawl with a tickler chain and 5-mm mesh size in the cod end. All trawls were carried out during the night, at high water of spring tides. Temperature, salinity, dissolved oxygen, $\mathrm{pH}$, and depth were measured simultaneously with crab samples' collections at each station. The distance covered by each trawl was determined using a portable GPS. Moreover, at each sampling station, sub-surface zooplankton samples were taken monthly, from June 2003 to May 2004, at high tide during the day, using a Bongo net of $0.5-\mathrm{m}$ mouth diameter and $335-\mu \mathrm{m}$ mesh size. A Hydro-Bios Flow-meter placed at the extremity of the net mouth quantified the volume of water filtered during each trawl. The sediment of the sampling stations was characterized from samples collected in the summer and autumn of 2003, and in the winter and spring of 2004, using a van Veen dredge.

\subsection{Laboratory procedures}

All crabs caught were counted, sexed, measured (carapace width, $\mathrm{CW}$, to the nearest $\mathrm{mm}$ ), and weighed (wet weight), and the reproductive condition (occurrence of females carrying eggs), colour morphotype ('green' and 'red'; according to McGaw and Naylor, 1992a,b), and the presence of moulting crabs were marked. Juvenile crabs were sexed by observing the presence/absence of the copulatory pleopods in individuals more than $4.3 \mathrm{~mm}$ (the smallest male where copulatory pleopods were visible). A total of 3663 crabs (1725 males and 1938 females) were examined. 
Length-weight relationships were determined for production estimates, providing a regression equation for females and males, respectively $\quad(A F D W=$ $0.00005 \mathrm{CW}^{2.8586}, \quad n=90, \quad r=0.99 ; \quad$ AFDW $=$ $\left.0.00005 \mathrm{CW}^{2.885}, n=98, r=0.99\right)$. Biomass was calculated as ash free dry weight (AFDW) (loss of ignition after $8 \mathrm{~h}$ of incineration at $450{ }^{\circ} \mathrm{C}$ of specimens previously dried at $60{ }^{\circ} \mathrm{C}$ for 10 days).

Zooplankton sub-samples were obtained for abundance estimates using a Folsom plankton splitter (Bourdillion, 1964). Carcinus maenas larvae were counted and identified according to the description by Rice and Ingle (1975). Density was expressed as number of individuals per cubic meter (ind $\mathrm{m}^{-3}$ ).

Dried sediment samples were incinerated at $450{ }^{\circ} \mathrm{C}$ for $8 \mathrm{~h}$ to estimate the percentage of organic matter. The different particle fractions were subsequently sorted through a set of sieves and weighed for sediment granulometry.

\subsection{Data analysis}

Modal distributions recognisable in successive sample dates were identified through size-frequency analysis. Computations were performed using the ANAMOD software (Nogueira, 1992), which is based on the probability paper method (Harding, 1949), as performed by Cassie $(1954,1963)$. The reliability of the method was tested employing the $\chi^{2}$ and $G$ tests $(P \leq 0.05)$.

A canonical correspondence analysis was used in order to evaluate the relationships between the spatial distribution of crabs' age classes and colour forms densities, for both sexes, with environmental parameters. Computations were performed using CANOCO (Ter Braak and Smilauer, 1998). Crabs density data were averaged by sampling area and season (summer, autumn, winter and spring). Temperature, salinity, dissolved oxygen, type of sediment, algae biomass, mean depth and benthos biomass were also included in the analysis as an environmental data matrix.

Annual average subtidal secondary production was estimated according to the size-frequency method modified by Benke (1979).

$$
P=a\left[\sum_{j=1}^{a-1}\left(\bar{N}_{j}-\bar{N}_{j+1}\right) \sqrt{\left(\bar{W}_{j} \bar{W}_{j+1}\right)}\right] \frac{365}{\mathrm{CPI}},
$$

where $\bar{N}_{j}$ is the mean density in size class $j\left(\right.$ ind m $\left.{ }^{-2}\right) ; \bar{W}_{j}$ the mean individual weight in size class $j$ (mg AFDW); CPI the cohort production interval, i.e. mean length of crabs life (days); and $j$ and $j+1$ the consecutive size classes $(j=1,2, \ldots, a)$.

\section{Results}

\subsection{Characterisation of the sampling areas}

The different sampling areas permit recognition of a typical estuarine gradient, with salinity, depth and dissolved oxygen increasing from the upstream to the downstream areas (Table 1). The least variable parameter in spatial terms was $\mathrm{pH}$, which showed only minor differences between sampling areas. Mouth sediments consisted mainly of fine to medium sand. The South arm and the Pranto River section exhibited similar sediment compositions, with a predominance of silts and clay, although the fine particles percentage was higher in the Pranto. The North arm sediments were mostly composed of medium to coarse sand. The Pranto presented the highest algal cover values $\left(\mathrm{g} \mathrm{m}^{-2}\right)$ and the Mouth exhibited the higher benthos biomass $\left(\mathrm{g} \mathrm{AFDW} \mathrm{m}^{-2}\right.$ ). Although the Secchi depth was not determined (as the sampling program took place during the night), highest turbidity is usually found at the Pranto (Verdelhos et al., 2005).

\subsection{Abundance and population size structure}

Only the first zoeae stage of Carcinus maenas was found in the zooplankton samples. It was found in all sampling stations through the year, being more abundant in January/February in the South arm (Fig. 2A). Benthic young juveniles ( $>10 \mathrm{~mm} \mathrm{CW}$ ) were also found all year round but almost exclusively at the Pranto (Fig. 2B). In order to evaluate the probable time of postlarval maximum recruitment, the density of individuals of less than $5 \mathrm{~mm}$ present in the Pranto samples was examined (Fig. 2C). Results suggest a continuous pattern of recruitment, although a clear increase occurred in spring, contrary to what has been observed

Table 1

Mean environmental characteristics (standard deviation) of the sampling areas

\begin{tabular}{lccrc}
\hline $\begin{array}{l}\text { Sampling } \\
\text { station }\end{array}$ & $\begin{array}{l}\text { Mouth } \\
(1)\end{array}$ & $\begin{array}{l}\text { South } \\
\text { arm (2) }\end{array}$ & \multicolumn{1}{l}{$\begin{array}{l}\text { Pranto } \\
(3)\end{array}$} & $\begin{array}{l}\text { North } \\
\text { arm (4) }\end{array}$ \\
\hline Salinity & $30.3(3.4)$ & $28.3(4.3)$ & $22.7(4.4)$ & $20.1(6.6)$ \\
Temperature $\left({ }^{\circ} \mathrm{C}\right)$ & $15.6(2.7)$ & $17.2(3.1)$ & $18(5.3)$ & $16.8(3.6)$ \\
$\mathrm{O}_{2}(\%)$ & $102.1(7.8)$ & $95.9(6.1)$ & $85.3(8.4)$ & $93.3(7.2)$ \\
$\mathrm{pH}$ & $8.2(0.1)$ & $8.1(0.2)$ & $7.8(0.2)$ & $8.1(0.1)$ \\
Mud (\%) & $2.6(2.9)$ & $4.4(3.1)$ & $8.9(1.7)$ & $0(0)$ \\
Silt $(\%)$ & $10.2(7.3)$ & $13.0(10.5)$ & $16.6(3.1)$ & $0(0)$ \\
Fine sand $(\%)$ & $43.8(22.8)$ & $45.5(8.2)$ & $43.7(7.8)$ & $2(1.6)$ \\
Medium sand $(\%)$ & $29.8(13.3)$ & $24.6(9.6)$ & $23.4(4.9)$ & $51.7(34.7)$ \\
Coarse sand $(\%)$ & $13.6(12.8)$ & $12.5(10.3)$ & $7.4(3.5)$ & $45.9(36.5)$ \\
$\begin{array}{l}\text { Depth } \\
\quad(h i g h \text { tide) }(\mathrm{m})\end{array}$ & $8.7(1.2)$ & $2.3(0.4)$ & $2.4(1)$ & $5.5(0.5)$ \\
Algae $\left(\mathrm{g} \mathrm{m}^{-2}\right)$ & $0.5(0.5)$ & $0.9(2.3)$ & $2.9(3.6)$ & $0(0)$ \\
Benthos & $3.6(5.3)$ & $0.4(0.2)$ & $1.2(1.2)$ & $0(0)$ \\
$\left.\quad \mathrm{g} \mathrm{AFDW} \mathrm{m}^{-2}\right)$ & & & & \\
\hline
\end{tabular}



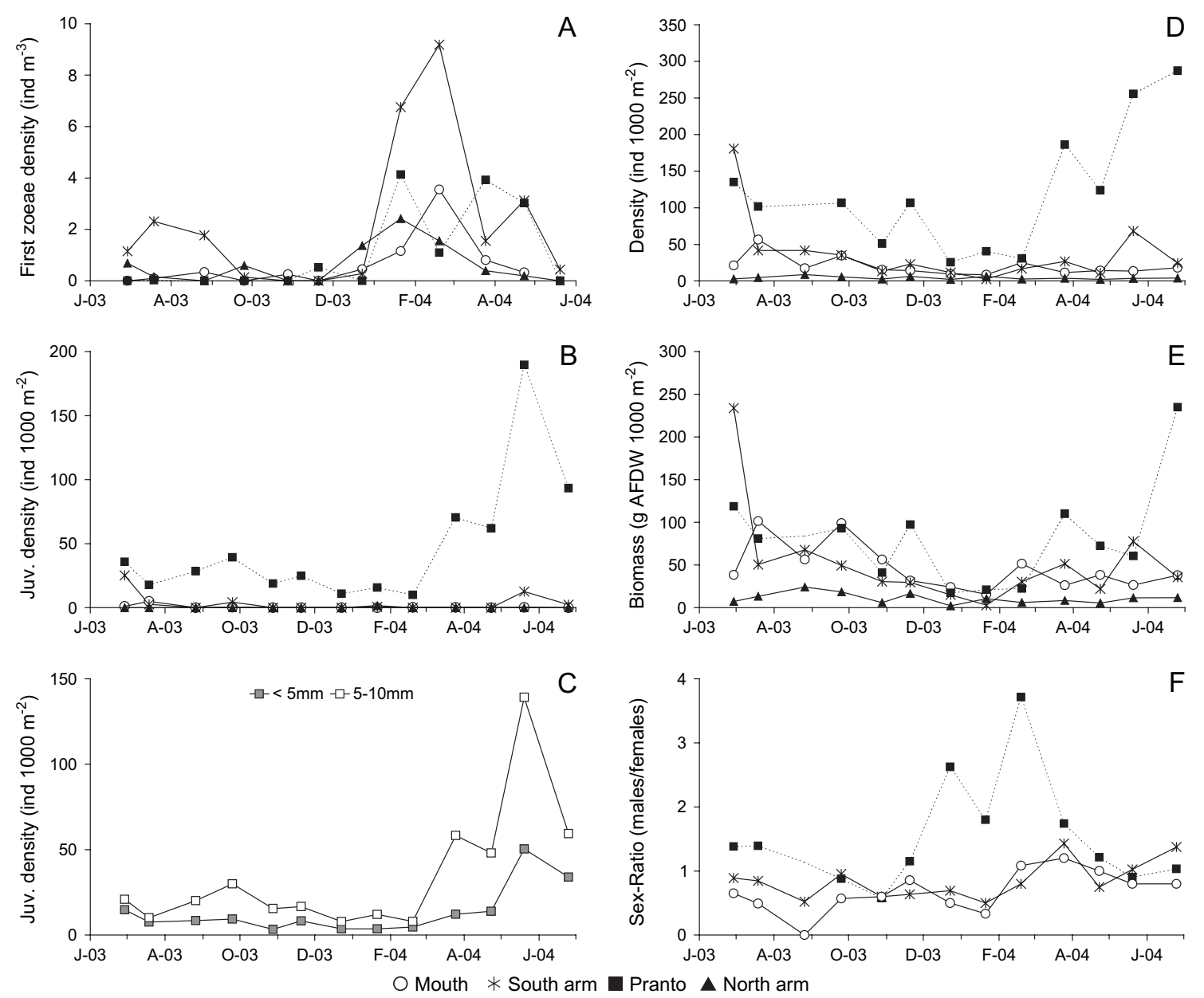

Fig. 2. Carcinus maenas' biological features. (A) Planktonic larvae density; (B) abundance of juveniles less than $10 \mathrm{~mm}$ carapace width; (C) abundance of juveniles between 5 and $10 \mathrm{~mm}$ and below $5 \mathrm{~mm}$ carapace width, just in Pranto station; (D) total abundance of the population; (E) total biomass of the population; (F) sex-ratio variation based only on juveniles ( $>35 \mathrm{~mm}$ ).

in other temperate systems (Queiroga, 1993; Sprung, 2001).

Differences in density were observed between sampling stations (Fig. 2D). Densities were much higher at Pranto (mean value of 116 ind $1000 \mathrm{~m}^{-2}$ and a maximum 287 ind $1000 \mathrm{~m}^{-2}$ ) particularly between March and June, which appears to be an obvious function of recruitment. In fact, differences in biomass between sampling stations were much less evident, and, despite presenting the highest densities, the Pranto did not show the highest biomasses (Fig. 2E). These observations, combined with other results (see below), suggest migration to downstream as individuals become older.

Few ovigerous females of Carcinus maenas were caught during the study period, and always in the downstream areas, with a maximum in June 2003 and February 2004. The average carapace width of females carrying eggs was $43 \mathrm{~mm}$, with the largest one being $64 \mathrm{~mm}$ and the smallest one $29 \mathrm{~mm}$. Most of the ovigerous females, nearly $70 \%$, belonged to the red female morphotype. Ovigerous female typically place themselves at active burrows, which forced us to estimate sex ratio based only on juvenile specimens. In these conditions, the sex-ratio was in general favourable to males in winter months, but we must emphasize that no juveniles at all were captured in the North arm.

Fig. 3 shows the size frequency distribution observed in male and female populations, which showed a similar structure throughout the year. Age classes $0+, 0++$, $1+, 2+, 3+$ and $4+$ were identified for both sexes (Fig. 4), corresponding to young juveniles, juveniles and individuals of 1,2, 3 and 4 years old, respectively, if we assume that Carcinus maenas reaches sexual maturity within the 30-40 mm size interval (Broekhuysen, 1936; Demeusey, 1958; Klein Breteler, 1975, 1976a,b).

As for the Brachyura in general, the size increment at each moult, relative to initial size, decreases with the size of the animals. The size increments for the different age classes in the present study were $29 \%, 20 \%$ and $13 \%$ for females with 33,43 and $52 \mathrm{~mm}$ carapace width, and $34 \%, 23 \%$ and $17 \%$ for males with 32,43 and $53 \mathrm{~mm}$ carapace width. These $\mathrm{CW}$ values are the mean of the 
Males
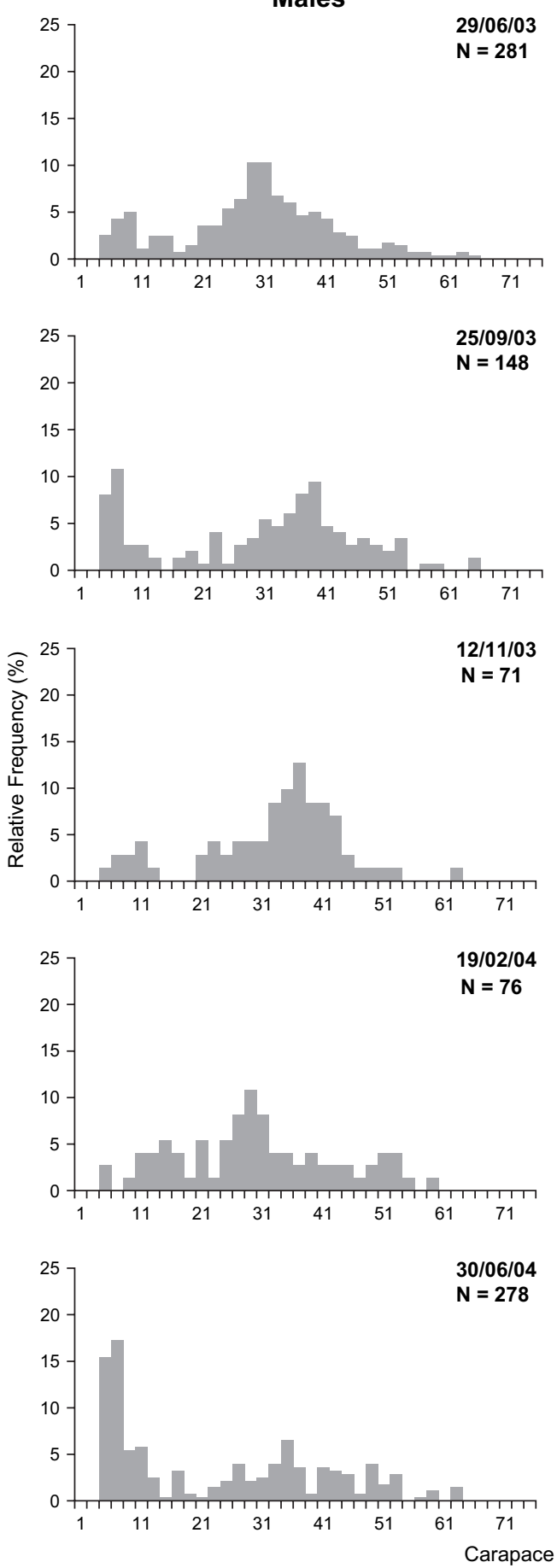
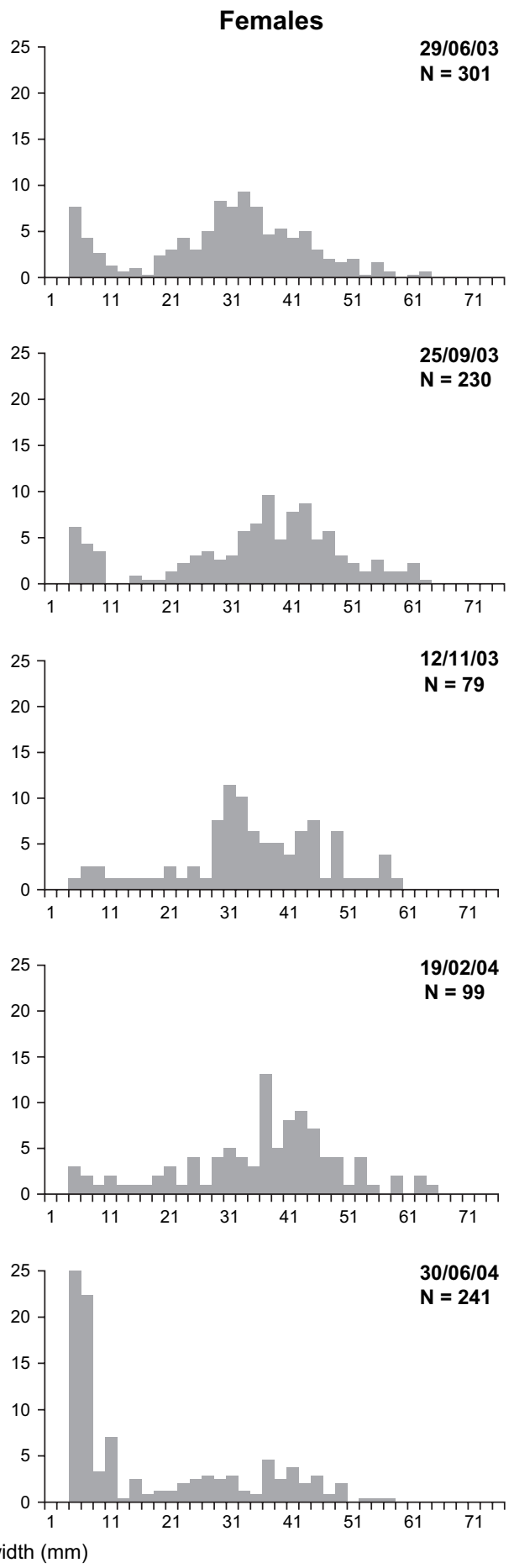

Fig. 3. Carcinus maenas. Size frequency distribution of males and females. Sampling dates are indicated. $N$, number of measured individuals.

values obtained during the study period for individuals of 1,2 and 3 years old.

\subsection{Colour morphotype variability and moulting}

The proportion of green crabs increased with increasing distance from the mouth of the estuary $(58 \%$, $89 \%, 98 \%$ and $72 \%$ at the Mouth, South arm, Pranto, and North arm, respectively). Regarding the whole set of individuals caught, the proportion of green crabs was $86 \%$, with green males $(93 \%$ of males) being more common than green females ( $81 \%$ of females).

The proportion of moulting crabs also increased from downstream to upstream areas $(2 \%, 8 \%, 16 \%$ and, $7 \%$ at the Mouth, South arm, Pranto and North arm, respectively). Moulting crabs represented $10 \%$ of the 


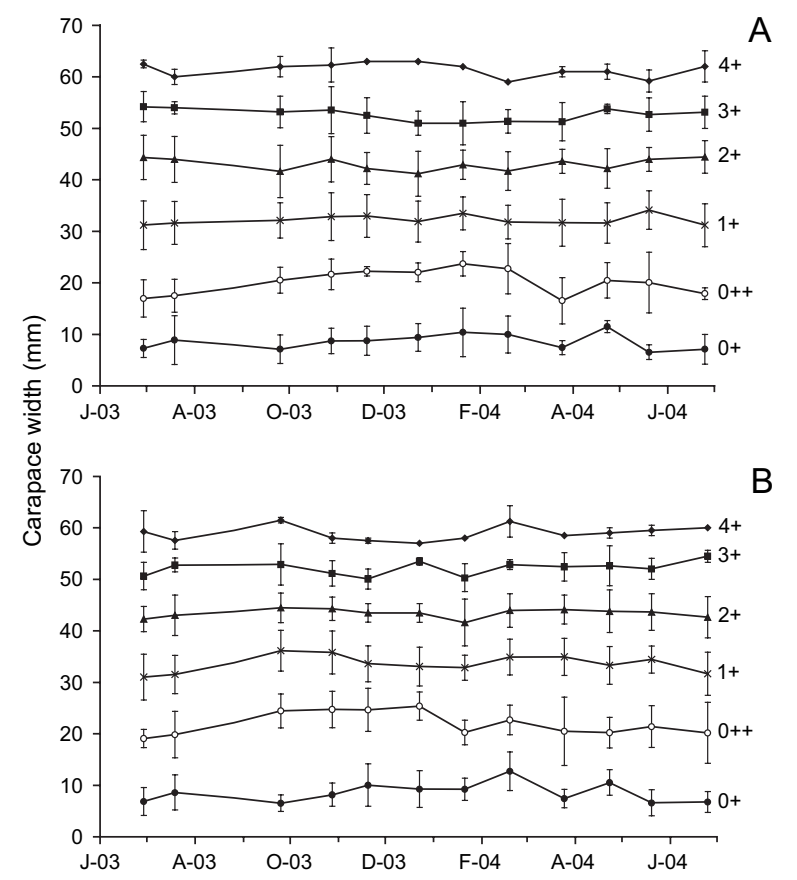

Fig. 4. Carcinus maenas. Age classes' variation of males (A) and females (B).

total number collected, of which $73 \%$ were caught at Pranto (42\% females and 58\% males). Although moulting crabs were found throughout the year, the main moulting seasons were from April to June, for males, and from July to October, for females.

\subsection{Spatial distribution}

The first two axes of the CCA performed on the crabs' age classes and colour forms data accounted for $75 \%$ of the total variance and $83 \%$ of variance due to age classes and color forms - environment relations. The ordination diagram (Fig. 5) shows the main pattern of distribution in the Carcinus maenas population representing the centres of the age classes and color forms distribution in relation to sampling stations and seasons and to environmental variables.

Juveniles $(\mathrm{F} 0+, \mathrm{F} 0++, \mathrm{M} 0+$ and $\mathrm{M} 0++)$ are found in the left edge of the diagram being positively correlated with algae and mud variables, and associated with Pranto, mainly connected to spring. Females $1+$ and males $1+, 2+, 3+$ are associated with the South arm downstream areas. Salinity and coarse sediment were positively correlated with these age classes. Females $2+, 3+, 4+$ and males $4+$ were associated with depth and medium sediment component found at further downstream areas (Mouth). The individuals found in the North arm were correlated with depth and medium sand sediment, although this relation had a low magnitude. Red females and red males were strongly associated with downstream areas (Mouth), and with

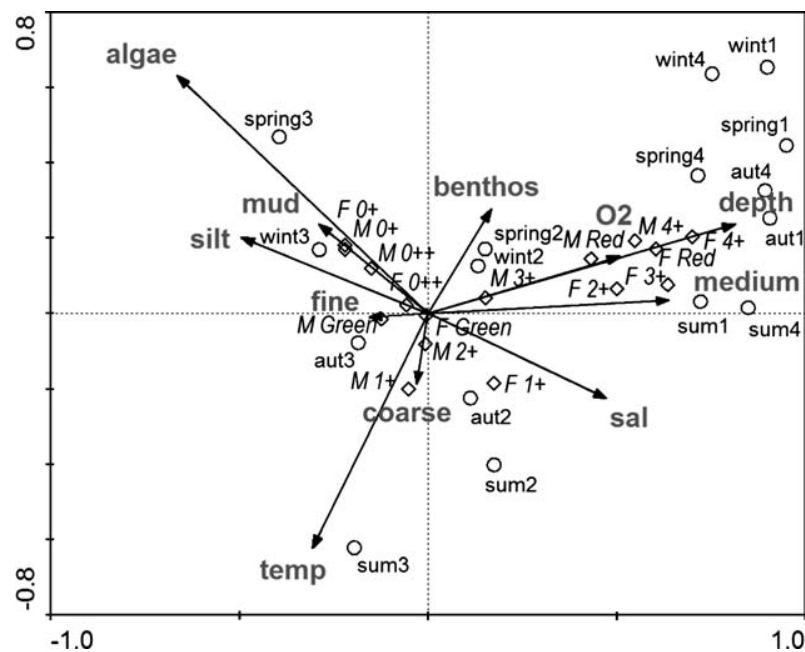

Fig. 5. Ordination diagram for the first two canonical axis of the correspondence analysis $(\mathrm{F} 0+, \mathrm{F} 0++, \mathrm{F} 1+, \mathrm{F} 2+, \mathrm{F} 3+, \mathrm{F} 4+-$ females; $\mathrm{M} 0+, \mathrm{M} 0++, \mathrm{M} 1+, \mathrm{M} 2+, \mathrm{M} 3+, \mathrm{M} 4+-$ males; $\mathrm{F}$ green - females green; $F$ red - females red; $M$ green - males green; $M$ red - males red; 1 - Mouth; 2-South arm; 3 - Pranto; 4-North arm; sum - summer; aut - autumn; wint - winter; spring - spring; temp temperature; sal - salinity; $\mathrm{O}_{2}$ - dissolved oxygen; mud - mud; silt silt; fine - fine sand; medium - medium sand; coarse - coarse sand; depth - depth; algae - algae biomass; benthos - benthos biomass).

depth and dissolved oxygen. Green crabs were associated with upstream areas and with the fine sediment variable.

\subsection{Life cycle}

Fig. 6 summarizes the life cycle of Carcinus maenas in the Mondego estuary. Benthic recruitment occurs mainly at upstream areas, which explains the higher proportion of juveniles at Pranto, but after reaching sexual maturity crabs tend to migrate to downstream areas. For this reason, the population at the South arm mainly consists

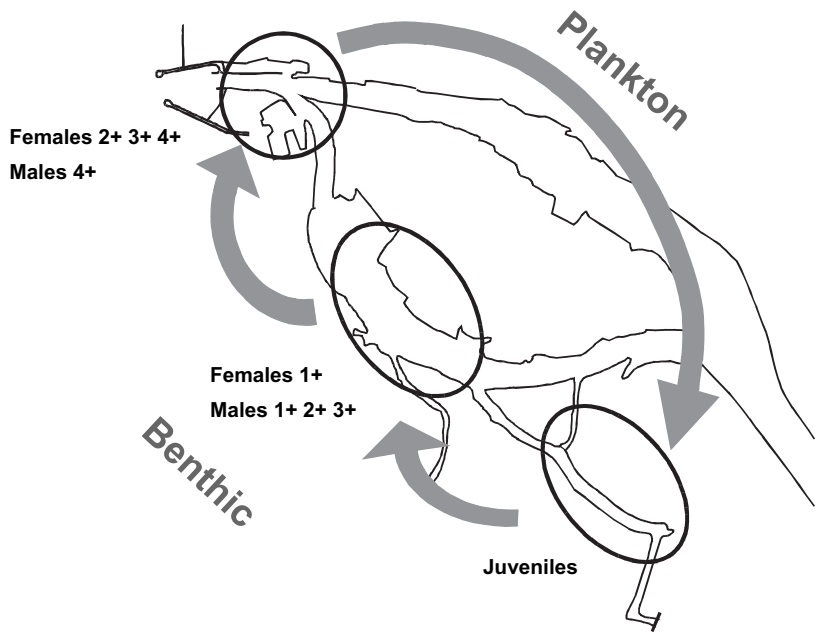

Fig. 6. The Carcinus maenas' life cycle in the Mondego estuary. 
of older than one-year-old crabs. Moreover, females more than one year old and the older males tend to continue their migration to downstream areas, the deeper part of the estuary, where females hatch their larvae. Based on the findings of Queiroga (1996) for the north coast of Portugal, a quick export of the first zoeae out of the estuary probably occurs, using selective tidal stream transport, and larval development takes place mainly in the ocean. The megalopae is the stage that reinvades the system, moving upstream to estuarine nursery areas for settlement.

\subsection{Production estimates}

The average annual growth production $(P)$ of the subtidal population of Carcinus maenas was estimated at $0.08 \mathrm{~g} \mathrm{~m}^{-2} \mathrm{y}^{-1}$ AFDW. The average annual biomass $(\bar{B})$ was estimated at $0.058 \mathrm{~g} \mathrm{~m}^{-2}$, resulting in a $P / \bar{B}$ ratio of 1.4 .

\section{Discussion}

Results obtained enabled a detailed assessment of some relevant data regarding the biology of the green crab Carcinus maenas in this temperate estuary. In general, the occurrence of this crab species in estuaries is well documented (e.g. Marques and Costa, 1984; Ameyaw-Akumfi and Naylor, 1987; McGaw and Naylor, 1992a; Queiroga et al., 1994; Cardoso et al., 2004), but the chronology of reproductive events in the Mondego estuary was found to be quite different from the patterns described in the literature (Table 2), not only from Northern Europe and North America, but also from other temperate zones. In Ria de Aveiro (Queiroga,
1993; Almeida and Queiroga, 2003) and in Ria Formosa (Sprung, 2001) settlement events can be detected from March onwards. In populations of Swansea (Naylor, 1962) recruitment is detected in June, in the Sweden coast in July (Moksnes, 2002), and in Maine in August (Berrill, 1982), indicating a latitudinal pattern. Also the breeding and the moulting season period increases from North to South. Nevertheless, in the Mondego estuary recruitment, breeding and moulting season can be detected throughout the year (Table 2).

In fact, in the Mondego estuary there is a continuous pattern of recruitment throughout the year, mainly at Pranto. This nursery area offers a set of favourable environmental characteristics to megalopae settlement and to the growth of juveniles. Actually, the Pranto is the shallowest subtidal area in the estuary, being characterized by muddy bottoms, high percentage of algae biomass and turbid waters, providing more food resources and shelters relatively to predation. This result is consistent to previous studies demonstrating that shore crab megalopae avoid open sand and choose to settle in structured substrates of different kind (Moksnes, 2002), that provide a refuge from predation (Moksnes et al., 1998) and also serve as a reservoir of small forms (Thiel and Dernedde, 1994). Abundance of small crabs in these structured substrates can be extremely high. In Zostera noltii patches in South Portugal, Sprung (2001) reported up to $50 \mathrm{crabs} \mathrm{m}^{-2}$, in Mytilus edulis clumps in Wadden Sea, Thiel and Dernedde (1994) more than $200 \mathrm{~m}^{-2}$, and Klein Breteler $(1976 \mathrm{a}, \mathrm{b})$ up to $600 \mathrm{~m}^{-2}$. Densities of over 1000 young juveniles $\mathrm{m}^{-2}$ from seagrass beds and mussel banks have been found in both the Wadden Sea and in Sweden (Scherer and Reise, 1981; Moksnes, 2002, respectively). The low juveniles density observed for the Mondego estuary in comparison to these observations are

Table 2

Summary of several parameters of Carcinus maenas populations according to the latitudinal variation

\begin{tabular}{|c|c|c|c|c|c|c|c|c|c|}
\hline References & Locality & $\begin{array}{l}\text { Ovigerous } \\
\text { females }\end{array}$ & Zoeae & Recruitment & $\begin{array}{l}\text { Moulting } \\
\text { season }\end{array}$ & Life span & $\begin{array}{l}\text { Maximum } \\
\text { CW width } \\
\text { (female; male) }\end{array}$ & $P$ & $P / \bar{B}$ \\
\hline Berrill, 1982 & Maine (USA) & Apr-Aug & - & Aug-Sep & Jun-Oct & $5-6$ years & $70 ; 82$ & - & - \\
\hline $\begin{array}{l}\text { Pihl and Rosenberg, } \\
\text { 1982; Pihl, 1986; } \\
\text { Moksnes et al., } 1998\end{array}$ & Sweden (west coast) & - & - & Jul-Sep & - & - & - & - & $4.5 ; 2.8$ \\
\hline Naylor, 1962 & Swansea (Wales) & Feb-Jun & Jul-Sep & Jun-Oct & May-Jan & $3-4$ years & $70 ; 86$ & - & - \\
\hline Broekhuysen, 1936 & $\begin{array}{l}\text { Den Helder } \\
\text { (The Netherlands) }\end{array}$ & Nov-Jul & May-? & Jun-Oct & May-Jan & $3-4$ years & $70 ; 86$ & - & - \\
\hline Demeusey, 1963 & Luc-sur-mer (France) & Nov-Jul & - & Jun-Oct & May-Jan & $3-4$ years & $70 ; 86$ & - & - \\
\hline $\begin{array}{l}\text { Queiroga, 1993; } \\
\text { Almeida and } \\
\text { Queiroga, 2003 }\end{array}$ & $\begin{array}{l}\text { Ria de Aveiro } \\
\text { (Portugal) }\end{array}$ & All year & All year & Apr-Oct & Feb-Oct & $3-4$ years & - & - & - \\
\hline This study & $\begin{array}{l}\text { Mondego estuary } \\
\text { (Portugal) }\end{array}$ & All year & All year & All year & All year & $3-4$ years & $65 ; 71$ & 0.08 & 1.38 \\
\hline Sprung, 1993, 2001 & $\begin{array}{l}\text { Ria Formosa } \\
\text { (Portugal) }\end{array}$ & - & Oct-May & Apr-Sep & - & - & - & - & 6.4 \\
\hline
\end{tabular}


probably due to the sampling technique, since the crabs were collected just from subtidal areas using a beam trawl, which is more adequate as a relative estimate for larger juveniles and adults that use the deeper, less structured habitats more frequently. Also the peak of abundance would not be very sharp, because the reproduction is not limited to only a restricted period.

Although this species breeds throughout the year, ovigerous females were more abundant during late winter and spring, being always captured downstream in the estuary, which apparently constitute the preferential spawning areas. The small number of ovigerous females captured in the present study might be explained as a selective advantage for these females to remain hidden and seek deeper more saline waters.

Carcinus maenas larvae release occurred all year round. Peak larval abundances, 10 larvae $\mathrm{m}^{-3}$, were low compared to other studies (e.g. Queiroga et al., 1994; Sprung, 2001). Queiroga's data show that the highest observed densities of first zoeae were about 150 larvae $\mathrm{m}^{-3}$, and Sprung obtained a peak larval abundance of about 160 larvae $\mathrm{m}^{-3}$. These different results are probably due to the time of the day and during the tidal period plankton samples were collected, since it is known that $C$. maenas larvae show highest peaks during nocturnal neap ebb tides (Queiroga et al., 1994).

The strongly biased juveniles' sex-ratio towards the males in upstream areas during the winter months indicates that females probably migrate to downstream areas, when they are near to reach maturity or ready to mate. The size increments at moult obtained in the present work were in the same range as the ones observed by Queiroga (1993) but were lower compared to other works (e.g. Broekhuysen, 1936; Demeusey, 1958). These data were obtained in experimental (optimal) conditions, which do not require an active search for food and other sources of stress, thus resulting in energy saving that can be directed to growth.

Carcinus maenas of the green morphotype are known to withstand a greater environmental stress than red crabs (McGaw and Naylor, 1992a,b; Reid et al., 1997), in particular in relation to osmotic and oxygen decreased tolerance. This is reflected in the relative distribution of the two forms: green crabs are found more frequently in estuarine and intertidal habitats than red crabs, which are most abundant in open shore subtidal habitats. Moreover, at estuarine sites red females are more abundant than red males (Crothers, 1968; McGaw and Naylor, 1992b; Reid et al., 1997). Thus, the pattern observed in the present field study is consistent with the ecophysiological differences reported in the literature between the 2 colour morphotypes. Our results also confirm that during moulting stage crabs tend to migrate to shallow waters and intertidal habitats, in order to avoid predation, as they are highly attractive to predators at this time (Reid et al., 1997).
The CCA analysis showed an intraspecific spatial variability connected to the migratory behaviour observed. This variability is associated with the size, sex and coloration of the individuals concerned. As stated before, these results are explainable if we account for the environmental variability in the study area. The field data also suggest that the Carcinus maenas population crabs are rare in the North arm, which does not present favourable conditions for the development of a stable population, probably due to strong currents, coarse sediments and common dredging activities related to the commercial harbour facilities.

The $P / \bar{B}$ ratio estimated in the present study was lower than in other European systems (Table 2), but we must take into account that in all previous studies the $P / \bar{B}$ ratio was estimated from intertidal areas' populations, where crabs are in average smaller (young grow faster) and densities are higher.

The present study revealed the occurrence of a differential spatial distribution in the population according to sex, size, moulting, and carapace coloration of the crabs inhabiting the Mondego estuary. This species spawn inside the estuary (at the mouth) and the first zoeae are mainly transported to coastal waters. Later occurs a reinvasion of the estuary by the megalopae stage, using selective tidal stream transport (Queiroga et al., 1997). This study reinforces the notion that the exchange of meroplankton between estuaries and open coastal waters are of extreme importance. Moreover, specifically it helps to clarify the distribution pattern and life cycle of this species that present a high ecologic relevancy at local and regional scales.

\section{Acknowledgements}

The present study was carried out in the scope of the research project "Dynamic model of stress induced changes on benthic communities" (POCTI/MGS/37431/ 2001) funded by the Portuguese FCT. A special thanks to all colleagues who helped during field work.

\section{References}

Abelló, P., Aagaard, A., Warman, C.G., Depledge, M.H., 1997. Spatial variability in the population structure of the shore crab Carcinus maenas (Crustacea: Brachyura) in a shallow-water, weakly tidal fjord. Marine Ecology Progress Series 147, 97-103.

Almeida, M.J., Queiroga, H., 2003. Physical forcing of onshore transport of crab megalopae in the northern Portuguese upwelling system. Estuarine, Coastal and Shelf Science 57, 1091-1102.

Ameyaw-Akumfi, C., Naylor, E., 1987. Spontaneous and induced components of salinity preference behaviour in Carcinus maenas. Marine Ecology Progress Series 37, 153-158.

Benke, A.C., 1979. A modification of the Hynes method for estimating secondary production with particular significance for multivoltine populations. Limnology and Oceanography 24, 168-171. 
Berrill, M., 1982. The life cycle of the green crab Carcinus maenas at the northern end of its range. Journal of Crustacean Biology 2 (1), 31-39.

Bourdillion, A., 1964. Quelques aspects du probléme de l'echantillonnage du plancton marin. Terre et la Vie 1, 77-93.

Broekhuysen, G.J., 1936. On development, growth and distribution of Carcinides maenas (L.). Archives Neerlandaises de Zoologie 2, 257-399.

Cardoso, P.G., Lillebø, A.I., Pardal, M.A., Ferreira, S.M., Marques, J.C., 2002. The effect of different primary producers on Hydrobia ulvae population dynamics: a case study in a temperate intertidal estuary. Journal of Experimental Marine Biology and Ecology 277, 173-195.

Cardoso, P.G., Pardal, M.A., Lillebø, A.I., Ferreira, S.M., Raffaelli, D., Marques, J.C., 2004. Dynamic changes in seagrass assemblages under eutrophication and implications for recovery. Journal of Experimental Marine Biology and Ecology 302, 233-248.

Cassie, R.M., 1954. Some uses of probability paper in the analysis of size-frequency distributions. Australian Journal of Marine and Freshwater Research 3, 513-522.

Cassie, R.M., 1963. Tests of significance for probability paper analysis. New Zealand Sciences Review 6, 474-482.

Cohen, A.N., Carlton, J.T., Fountain, M., 1995. Introduction, dispersal and potential impacts of the green crab Carcinus maenas in San Francisco Bay, California. Marine Biology 122 (2), 225-237.

Crothers, J.H., 1968. The biology of the shore crab Carcinus maenas (L.). I. The background anatomy, growth and life history. Field Studies 2 (3), 407-434.

Dawirs, R.R., Dietrich, A., 1985. Temperature and growth in Carcinus maenas L. (Decapoda: Portunidae) larvae reared in the laboratory from hatching through metamorphosis. Journal of Experimental Marine Biology and Ecology 100, 47-74.

Demeusey, N., 1958. Recherches sur la mue de puberté du Decapode Brachyoure Carcinus maenas linné. Archives de Zoologie Experimentale et Generale 95, 253-492.

Demeusey, N., 1963. Influence des facteurs saisonniers sur la realisation de la puberté au sein d'une population de Carcinus maenas L. des côtes de la Manche. Comptes Rendus Hebdomadaires des Seances de l'Academie des Sciences 256, $4762-4764$.

Dolbeth, M., Pardal, M.A., Lillebø, A.I., Azeiteiro, U., Marques, J.C., 2003. Short- and long-term effects of eutrophication on the secondary production of an intertidal macrobenthic community. Marine Biology 143, 1229-1238.

Harding, J.P., 1949. The use of probability paper for the graphical analysis of polymodal frequency distributions. Journal of the Marine Biological Association of United Kingdom 28, 141-153.

Hunter, E., Naylor, E., 1993. Intertidal migration by the shore crab Carcinus maenas. Marine Ecology Progress Series 101, 131-138.

Klein Breteler, W.C.M., 1975. Food consumption, growth and energy metabolism of juvenile shore crabs, Carcinus maenas. Netherlands Journal of Sea Research 9 (3-4), 255-272.

Klein Breteler, W.C.M., 1976a. Migration of the shore crab Carcinus maenas, in the Dutch Wadden Sea. Netherlands Journal of Sea Research 10 (3), 338-353.

Klein Breteler, W.C.M., 1976. Settlement, growth and production of the shore crab, Carcinus maenas, on tidal flats in the Dutch Wadden Sea. Netherlands Journal of Sea Research 10 (3), 354-376.

Marques, J.C., Costa, I., 1984. Étude d'une collection de crustaces decapodes de l'estuaire du Tage (Portugal). Biologie des populations de Carcinus maenas (Decapoda, Brachyura), Crangon crangon, Palaemon longirostris e Palaemon serratus (Decapoda, Caridae). Ciência Biológica. Ecology and Systematics 5, 151-190.

Marques, J.C., Pardal, M.A., Nielsen, S.N., Jørgensen, S.E., 1997. Analysis of the properties of exergy and biodiversity along an estuarine gradient of eutrophication. Ecological Modelling 102, 155-167.
Marques, J.C., Nielsen, S.N., Pardal, M.A., Jørgensen, S.E., 2003. Impact of eutrophication and river management within a framework of ecosystem theories. Ecological Modelling 166, 147-168.

Martins, I., Pardal, M.A., Lillebø, A.I., Flindt, M.R., Marques, J.C., 2001. Hydrodynamics as a major factor controlling the occurrence of green macroalgal blooms in a eutrophic estuary: a case study on the influence of precipitation and river management. Estuarine, Coastal and Shelf Science 52, 165-177.

McGaw, I.J., Naylor, E., 1992a. Distribution and rhythmic locomotor patterns of estuarine and open-shore populations of Carcinus maenas. Journal of the Marine Biological Association of the United Kingdom 72, 599-609.

McGaw, I.J., Naylor, E., 1992b. Salinity preference of the shore crab Carcinus maenas in relation to coloration during intermoult and to prior acclimation. Journal of Experimental Marine Biology and Ecology 155, 145-159.

Mohamedeen, H., Hartnoll, R.G., 1989. Larval and postlarval growth of individually reared specimens of the common shore crab Carcinus maenas L. Journal of Experimental Marine Biology and Ecology 134, 1-24.

Moksnes, P.-O., Phil, L., Montfrans, J., 1998. Predation on postlarvae and juvenile of the shore crab Carcinus maenas: importance of shelter, size and cannibalism. Marine Ecology Progress Series 166, 211-225.

Moksnes, Per-Olav, 2002. The relative importance of habitat - specific settlement, predation and juvenile dispersal for distribution and abundance of young juvenile shore crabs Carcinus maenas L. Journal of Experimental Marine Biology and Ecology 271, 41-73.

Naylor, E., 1962. Seasonal changes in a population of Carcinus maenas (L.) in the littoral zone. The Journal of the Animal Ecology 31 (1), $601-610$

Nogueira, A.J., 1992. ANAMOD - Extracção dos componentes modais de distribuições de frequências de variáveis biométricas. Provas de aptidão pedagógica e capacidade científica. University of Coimbra, Coimbra, 67 pp.

Pardal, M.A., Marques, J.C., Metelo, I., Lillebø, A.I., Flindt, M.R., 2000. Impact of eutrophication on the life cycle, population dynamics and production of Ampithoe valida (Amphipoda) along an estuarine spatial gradient (Mondego estuary, Portugal). Marine Ecology Progress Series 196, 207-219.

Pardal, M.A., Cardoso, P.G., Sousa, J.P., Marques, J.C., Raffaelli, D., 2004. Assessing environmental quality: a novel approach. Marine Ecology Progress Series 267, 1-8.

Pihl, L., 1986. Exposure, vegetation and sediment as primary factors for mobile epibenthic faunal community structure and production in shallow marine soft bottom areas. Netherlands Journal of Sea Research 20, 75-83.

Pihl, L., Rosenberg, P., 1982. Production, abundance and biomass of mobile epibenthic marine fauna in shallow waters, western Sweden. Journal of Experimental Marine Biology and Ecology 57, 273-301.

Queiroga, H., 1993. An analysis of the size structure of Carcinus maenas (L.) (Decapoda, Brachyura) from Canal de Mira, Ria de Aveiro, Portugal. Biosis 1 (1), 89-106.

Queiroga, H., 1996. Distribution and drift of the crab Carcinus maenas (L.) (Decapoda; Portunidae) larvae over the continental shelf off northern Portugal in April 1991. Journal of Plankton Research 18, 1981-2000.

Queiroga, H., Costlow, J.D., Moreira, M.H., 1994. Larval abundance patterns of Carcinus maenas (Decapoda, Brachyura) in Canal de Mira (Ria de Aveiro, Portugal). Marine Ecology Progress Series 111, 63-72.

Queiroga, H., Costlow, J.D., Moreira, M.H., 1997. Vertical migration of the crab Carcinus maenas first zoeae in an estuary: implications for tidal stream transport. Marine Ecology Progress Series 149, 121-132.

Reid, D.G., Abelló, P., Kaiser, M.J., Warman, C.G., 1997. Carapace colour, inter-moult duration and physiological ecology of the shore crab Carcinus maenas. Estuarine, Coastal and Shelf Science 44, 203-211. 
Rice, A.L., Ingle, R.N., 1975. The larval development of Carcinus maenas (L.) and Carcinus mediterraneus Czerniavsky (Crustacea, Brachyura, Portunidae) reared on the laboratory. Bulletin of the British Museum of Natural History (Zoology) 28, 103-119.

Scherer, B., Reise, K., 1981. Significant predation on micro- and macrobenthos by the shore crab Carcinus maenas L. in the Wadden Sea. Kieler Meeresforschungen 5, 490-500.

Sprung, Martin, 1993. Estimating macrobenthic secondary production from body weight and biomass: a field test in a nonboreal intertidal habitat. Marine Ecology Progress Series 100, $103-109$.

Sprung, M., 2001. Larval abundance and recruitment of Carcinus maenas L. close to its southern geographic limit: a case of match and mismatch. Hydrobiologia 449, 153-158.
Ter Braak, C.J.F., Smilauer, P., 1998. CANOCO reference manual and user's guide to Canoco for Windows: software for Canonical Community Ordination (version 4). Microcomputer Power, Ithaca, NY, USA, $352 \mathrm{pp}$.

Thiel, M., Dernedde, T., 1994. Recruitment of shore crabs (Carcinus maenas) on tidal flats flats: mussel clumps as an important refuge for juveniles. Helgolaender Meeresuntersuchungen 48, 321-332.

Verdelhos, T., Neto, J.M., Marques, J.C., Pardal, M.A., 2005. The effect of eutrophication abatement on the bivalve Scrobicularia plana. Estuarine, Coastal and Shelf Science 63, 261-268.

Warman, C.G., Reid, D.G., Naylor, E., 1993. Variation in the tidal migratory behaviour and rhythmic light-responsiveness in the shore crab, Carcinus maenas. Journal of the Marine Biological Association of the United Kingdom 73, 355-364. 